Arab Univ. J. Agric. Sci., Ain Shams Univ., Cairo, Egypt 28(3), 749-765, 2020

Website: http://ajs.journals.ekb.eg

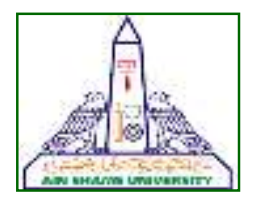

\title{
IMPROVING THE MANAGEMENT OF WASTEWATER REUSE TO IRRIGATE LANDSCAPE
}

\author{
EI-Shymaa H.E. Eldeep ${ }^{*}$, Hegazi M.M. and Bedair O.M.A. \\ Agric. Engineering Dept., Fac. Agric., Ain Shams Univ., P.O. Box 68, Hadayek Shoubra 11241, \\ Cairo, Egypt \\ ${ }^{*}$ Corresponding author: Elshymaa Hamed@agr.asu.edu.eg
}

[55]

Received 21 July, 2020

Accepted 17 September, 2020

\section{ABSTRACT}

This study aimed to measure the effect of treated wastewater on the performance of pressure irrigation network components and compare it with domestic water. The experiments were conducted in Eastown and Lake View sites in the Fifth Settlement - New Cairo, at $\mathrm{N}=30^{\circ} 01^{\prime} 14.4^{\prime \prime}, \mathrm{E}=31^{\circ} 51^{\prime}$ $60.9^{\prime \prime}$ and $\mathrm{N}=30^{\circ} 02^{\prime} 22 ", \mathrm{E}=31^{\circ} 44^{\prime} 31.3^{\prime \prime}$, respectively, and the experiments were done in (2019). The area under investigation was $155 \mathrm{~m}^{2}$, divided into three plots $(5 \times 5 \mathrm{~m})$ for spray irrigation, there areas were planted with turf grass (passpalm 10), and three plots $(5 \times 2 \mathrm{~m})$ for drip irrigation, there areas were planted with shrubs (Lantana camara nana) and trees (Calistemon viminalis). By irrigation with two types of water: treated wastewater and domestic water with the use of two types of filters in the Lake View site (a screen filter and a sandy filter) and the use of one type of filters in the Eastown site, which is screen filter. The washing process was carried out manually and automatically. The results showed significant effects on the components of the network and on the general appearance of the vitality and shape of the cultivated surfaces. The most important results obtained were:

- Emission uniformity for drip system in Lake View site, was higher when using automatic operation with treated wastewater by (5 and 6\%) for on-line dripper and built-in dripper, respectively, than manual operation, while, in Eastown site emission uniformity was higher when using automatic operation with treated wastewater by (2.3 and $4.9 \%)$ for on-line dripper and built-in dripper, respectively, than manual operation.

- Distribution uniformity for spray system was higher when using automatic operation with
\end{abstract}

treated wastewater by (5 and 5.1\%) in Lake View site and Eastown site, respectively, than manual operation.

- Clogging ratio in Lake View site by using manual operation with treated wastewater was (40 and $48 \%$ ) for on-line dripper and built-in dripper, respectively. Clogging ratio using automatic operation was (20 and 25\%) for on-line dripper and built-in dripper, respectively, while, in Eastown site by using manual operation with treated wastewater was (34.5 and $44.7 \%$ ) for on-line dripper and built-in dripper, respectively, and by using automatic operation was (18.75 and $22 \%$ ) for online dripper and built-in dripper, respectively. It was higher with manual operation than automatic operation and higher with treated wastewater than domestic water.

- The concentration of total suspended solids was less by (93.6 and $97.9 \%$ ) with manual and automatic operations, respectively in Lake View site, while, it was less by (50 and 60\%) with manual and automatic operations, respectively, in Eastown site.

- The turf quality index (color, density, ground cover) gave the highest degree when using treated wastewater with automatic operation, which is due to the nutrients in treated wastewater.

- It is preferable to use sand filters before the mesh filters with treated wastewater to reduce the percentage of clogging with impurities instead of using only mesh filters.

Keywords: Wastewater, Emission Uniformity, Clogging, Water management, Filters 


\section{INTRODUCTION}

Treated wastewater (TWW) is considered a good irrigation source for both arid and semi-arid areas. TWW has been used in some areas for agricultural activities in areas where freshwater resources are scarce (Carr et al 2011).

Water reuse is an economical alternative in developing water resources because it can save more than half the cost of producing desalinated water (Hamoda, 2004)

Guidelines for the safe use of treated wastewater (TWW)) were published by the World Health Organization (WHO, 2006). These guidelines were meant to be used as the foundation to develop international and national approaches to manage the health risks of the use of wastewater in agriculture. Moreover, there is a need for public awareness campaigns to address the social, legal, economic and institutional considerations for treated wastewater reuse (Mizyed, 2013). It could prove useful if a clear explanation is made as to why water reuse is a considered a valid solution (Hochstrat et al 2008).

Clogging of irrigation system is directly to the quality of irrigation water, in which the suspended impurities and chemical composition are prominent. These factors decide the type of water treatment required for prevention of clogging. The basic objective of the filtration system is to prevent quality irrigation water when it passes through a filtration system (Kumar et al 2017).

Emitter clogging is associated with effluent quality. Several factors can influence treatment clogging prevention including suspended particles, chemical composition and population. While filtration can essentially help avoid emitter clogging, it does not prevent it completely (Nakayama et al 2007).
Water management requires the use of the right amount of water, at the right time and in the right place. A water budget program, whether handwritten or digitalized, can ensure the right amount of water is used within your specific site budget (Juan, 2014).

\section{Objectives of this study are}

1- Studying the effect of irrigation systems by using domestic and treated wastewater on the clogging of emitters.

2- Studying the effect of domestic and treated wastewater on the efficiency of filters in Lake View and Eastown sites.

3- Studying the effect of using domestic and treated wastewater on emission uniformity for drip system and distribution uniformity for spray system.

4- Studying the effect of using domestic and treated wastewater on turf quality index (color - density and ground cover \%) for lawn plant (paspalum 10).

\section{MATERIALS AND METHODS}

\section{Experiment Location}

Field experiments were carried out at Eastown and Lake view sites located in New Cairo, Egypt at $\mathrm{N}=30^{\circ} 01^{\prime} 14.4^{\prime \prime}, \mathrm{E}=31^{\circ} 51^{\prime} 60.9^{\prime \prime}$ and $\mathrm{N}=30^{\circ} 02^{\prime}$ $22 ", E=31^{\circ} 44^{\prime} 31.3^{\prime \prime}$, respectively.

\section{Field Experiment Layout and Design}

The area of the experiment was $\left(155 \mathrm{~m}^{2}\right)$, divided into three plots $(5 \times 5 \mathrm{~m})$ for spray irrigation, there areas were planted with turf grass (passpalm 10), and three plots $(5 \times 2 \mathrm{~m})$ for drip irrigation, there areas were planted with shrubs (Lantana camara nana) and trees (Calistemon viminalis). Every treatment will be have three replicates as shown in Fig. 1. 


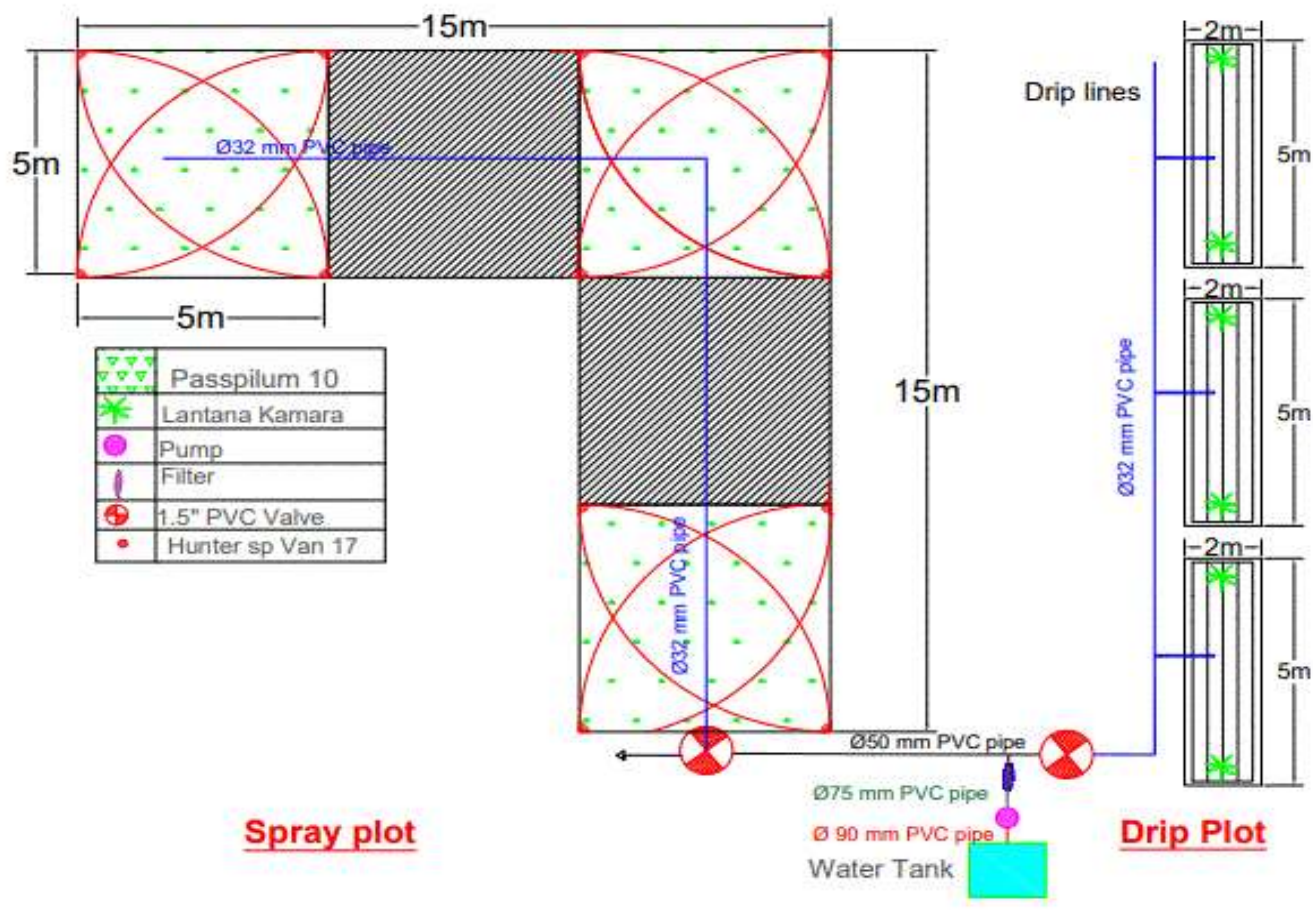

Fig. 1. Layout of the experimental site turf irrigation system in Lake View and Eastown sites

\section{Treatments}

\section{1- Water quality}

Domestic and treated wastewater were used to study the effect of them on emission uniformity (EU) for emitters, clogging of emitters, distribution uniformity (DU) for spray irrigation, filtration efficiency and turf quality index.

\section{2- Irrigation systems}

- Spray Irrigation (SI). Pop up spray used in the experiment for turf with discharge of $1.08 \mathrm{~m}^{3} / \mathrm{h}$, at operating pressure 2 bar, average precipitation rate of $42 \mathrm{~mm} / \mathrm{h}$ and radius of $5.1 \mathrm{~m}$ in Lake View and Eastown sites to irrigate turfgrass (paspalum10).

\section{- Drip irrigation (DI).}

$>$ In Eastown site, two types of emitters were used are:

- On-line emitter (Self-compensative) with discharge of $8 \mathrm{~L} / \mathrm{h}$ at pressure 1 bar and used 4 emitters per tree.
- Built-in emitter (Non self-compensative) with discharge of $8 \mathrm{~L} / \mathrm{h} / \mathrm{m}$ at pressure 1 bar and $0.5 \mathrm{~m}$ spacing between the emitters.

$>$ In Lake view site, two types of emitters were used are:

- On-line emitters (self-compensative) with discharge of $8 \mathrm{~L} / \mathrm{h}$ at pressure 1 bar and used 4 emitters per tree.

- Built-in emitters (self-compensative) with discharge of $8 \mathrm{~L} / \mathrm{h} / \mathrm{m}$ at pressure 1 bar and $0.5 \mathrm{~m}$ spacing between the emitters.

\section{3- Filtration system}

Two types of filters were used (screen and media) filters with automatic and manual operation backwashing.

- In Eastown site, used screen filters (120 mesh and discharge $300 \mathrm{~m}^{3} / \mathrm{h}$ at head loss 0.2 bar).

In Lake view site, screen filter was used (4" diameter with 120 mesh and discharge of $50 \mathrm{~m}^{3} / \mathrm{h}$ at head loss 0.05 bar), and media filter was used (4" diameter with discharge of $50 \mathrm{~m}^{3} / \mathrm{h}$ at head loss 0.06 bar). The specifications of filters were presented in Table 1 and 2. 
Table 1. Specifications of media filter used in Lake View site.

\begin{tabular}{|l|c|}
\hline \multicolumn{1}{|c|}{ Parameter } & Specifications \\
\hline Height of filter. & $1100 \mathrm{~mm}$ \\
Inlet dimeter. & $100 \mathrm{~mm}$ \\
Outlet dimeter. & $100 \mathrm{~mm}$ \\
Body diameter. & $1200 \mathrm{~mm}$ \\
Weight. & $310 \mathrm{~kg}$ \\
Back flushing. & $95 \mathrm{~m}^{3} / \mathrm{h}$ \\
Maximum pressure. & $10 \mathrm{bar}$ \\
Flow rate. & $50 \mathrm{~m}^{3} / \mathrm{h}$ \\
Effective diameter & $1 \mathrm{~mm}$ \\
\hline
\end{tabular}

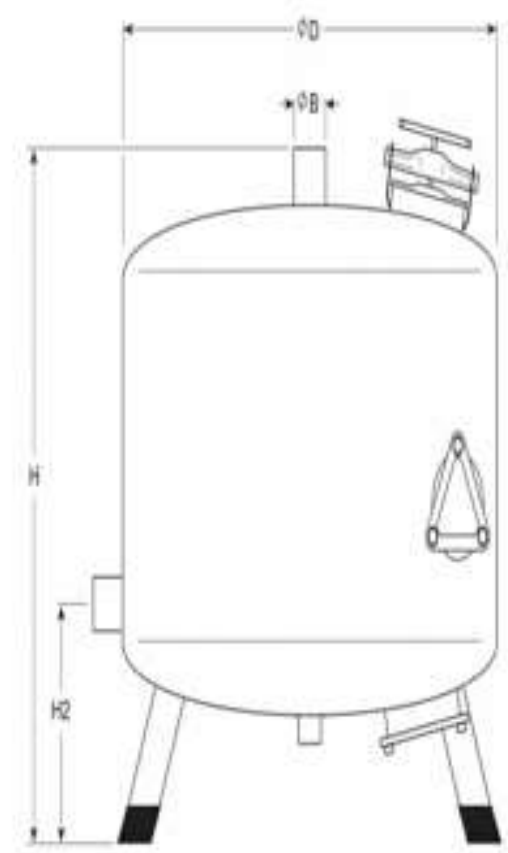
B: 4inch
$\mathrm{H}:$ 43inch
D: 48inch
H2: 10.7inch

Table 2. Specifications of screen filter used in Lake View and Eastown sites.

\begin{tabular}{|c|c|c|c|}
\hline \multicolumn{2}{|c|}{$\begin{array}{l}\text { Screen filter in Eastown } \\
\text { site }\end{array}$} & \multicolumn{2}{|c|}{$\begin{array}{c}\text { Screen filter in Lake } \\
\text { View site }\end{array}$} \\
\hline Inlet dimeter. & $250 \mathrm{~mm}$ & $\begin{array}{l}\text { Height of } \\
\text { filter. }\end{array}$ & $640 \mathrm{~mm}$ \\
\hline Outlet dimeter. & $250 \mathrm{~mm}$ & Inlet dimeter. & $100 \mathrm{~mm}$ \\
\hline $\begin{array}{c}\text { Number of } \\
\text { mesh }\end{array}$ & 120 mesh & $\begin{array}{c}\text { Outlet } \\
\text { dimeter. }\end{array}$ & $100 \mathrm{~mm}$ \\
\hline Weight. & $165 \mathrm{~kg}$ & $\begin{array}{c}\text { Body } \\
\text { diameter. }\end{array}$ & $200 \mathrm{~mm}$ \\
\hline Length of filter & $2302 \mathrm{~mm}$ & $\begin{array}{c}\text { Number of } \\
\text { mesh }\end{array}$ & $\begin{array}{c}120 \\
\text { mesh }\end{array}$ \\
\hline $\begin{array}{c}\text { Screen } \\
\text { cartridge } \\
\text { length }\end{array}$ & $1812 \mathrm{~mm}$ & $\begin{array}{l}\text { Maximum } \\
\text { pressure. }\end{array}$ & 10 bar \\
\hline $\begin{array}{l}\text { Maximum } \\
\text { pressure. } \\
\text { Flow rate. }\end{array}$ & $\begin{array}{c}10 \mathrm{bar} \\
300 \mathrm{~m}^{3} / \mathrm{h}\end{array}$ & Flow rate. & $50 \mathrm{~m}^{3} / \mathrm{h}$ \\
\hline
\end{tabular}

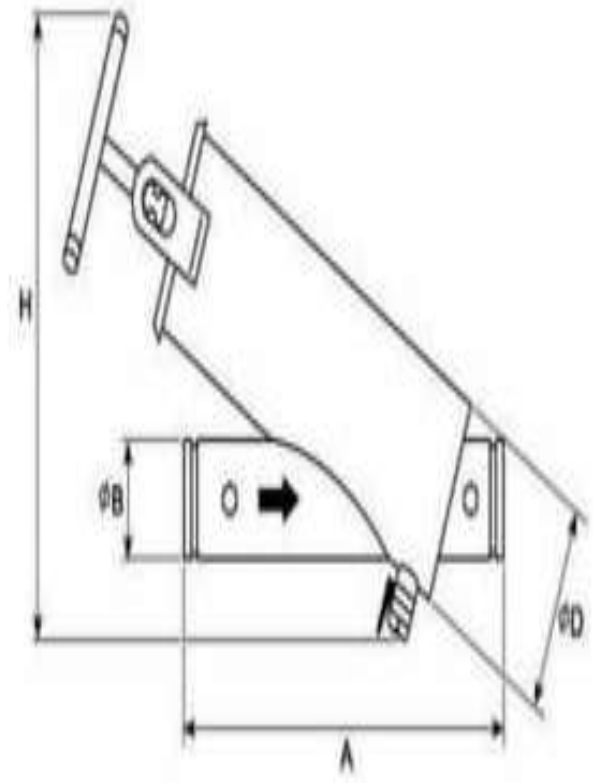
A: $690 \mathrm{~mm}$
D: $200 \mathrm{~mm}$
B: $100 \mathrm{~mm}$
$\mathrm{H}: 640 \mathrm{~mm}$

Fig. 2. Media filter in Lake View site

Fig. 3. Screen filter in Lak View site 


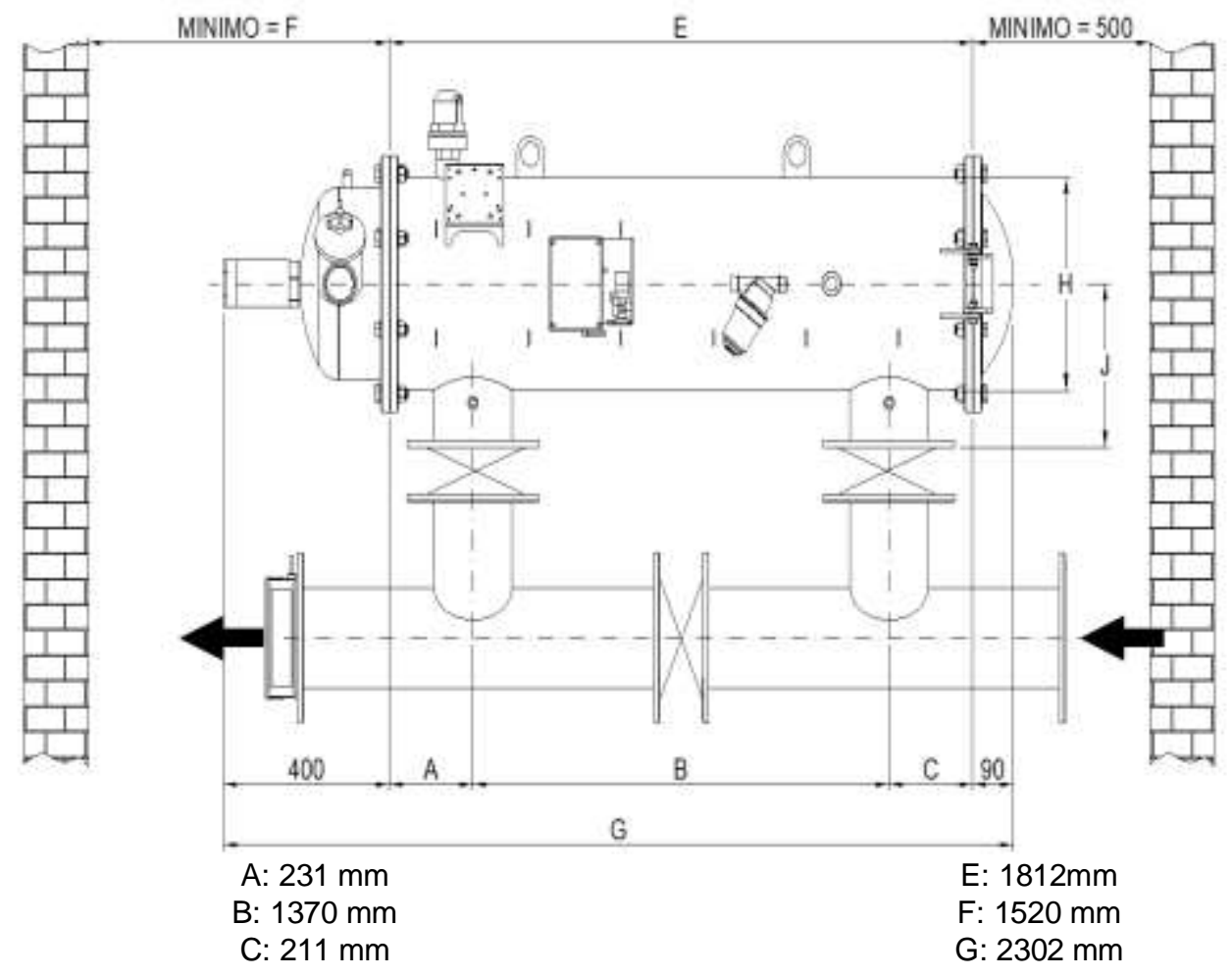

Fig. 4. Screen filter in Eastown site

Actual site conditions under investigation including engineering and hydraulic criteria of irrigation system

Table 3 shows site conditions under investigation including engineering and hydraulic criteria of irrigation system and management operation system, for Eastown and Lake View.

\section{Laboratory analysis of treated wastewater for Lake View and Eastown sites}

Some of the chemical characteristics for domestic water and treated wastewater were carried out in Central Laboratory, Faculty of Agricultural, Ain Shams University. Shoubra El- Khaima, Qalubia Covernorate. The samples of treated wastewater were taken before and after filters and allowable limits of using treated wastewater according to Pescod's (1992). All analysis of treated wastewater and domestic water were presented in Table 4 and 5.

\section{Climatic data in Lake View and Eastown sites}

The average climatic data during the months of the experiments in 2019 were obtained from Central Laboratory for Agricultural Climate (CLAC) for Lake View and Eastown sites as shown in Table (6).

\section{Measurements and calculations}

\section{Emission uniformity for drip system}

Emission uniformity was used to indicate performance for drippers. Values which were calculated according to the following equation (Keller and Karmeli, 1974):

$$
E U=\left(q_{n} / q_{a}\right) \times 100
$$

Where:

$\mathbf{E U}=$ the emission uniformity, \%.

$\mathbf{q}_{\mathbf{n}}=$ The average of the lowest $1 / 4$ of the drippers flow rate, $\mathrm{L} / \mathrm{h}$.

$q_{a}=$ The average of all dripper flow rate, $L / h$. 


\section{Distribution Uniformity for spray system}

The distribution uniformity was measured by conducting a catch-can test and comparing the average of the lower quarter of the samples with the overall average of samples (Irrigation Association, 2001). Good distribution uniformity was indicated by the average values of the lower quarter being similar to the overall average.

The lower quarter distribution uniformity (DULQ) was calculated with the following method:

$$
D U_{L Q}=100 \times\left(V_{L Q} / \text { Vavg }\right)
$$

Where:

$D U_{L Q}=$ Lower-quarter distribution uniformity, \%.
$\mathrm{V}_{\mathrm{LQ}}=$ Average low quarter, $\mathrm{ml}$.

$\mathrm{V}_{\mathrm{avg}}=$ Total average, $\mathrm{ml}$.

Rating of Lower Quarter Distribution Uniformity (DULQ) for Sprays as shown Table 7.

\section{Emitters clogging ratio}

Clogging ratio was calculated according to (AlAmoud. 1997) using the following equations:

$$
C R=(1-(Q u \div Q n))^{*} 100
$$

\section{Where:}

$\mathrm{CR}=$ The emitter clogging ratio, \%.

$\mathrm{Qu}=$ Average flow rate at start up operating, $\mathrm{L} / \mathrm{h}$.

$\mathrm{Qn}=$ Average flow rate at the end operating, $\mathrm{L} / \mathrm{h}$.

\begin{tabular}{|c|c|c|c|c|c|}
\hline & Site conditions & \multicolumn{2}{|c|}{ Eastown } & \multicolumn{2}{|c|}{ Lake view } \\
\hline$\Phi$ & Lawn & \multicolumn{2}{|c|}{26250} & \multicolumn{2}{|c|}{267000} \\
\hline 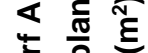 & Shrubs and G.C. & \multicolumn{2}{|c|}{48750} & \multicolumn{2}{|c|}{133000} \\
\hline & Palm and trees & \multicolumn{2}{|c|}{3000} & \multicolumn{2}{|c|}{12000} \\
\hline \multirow{4}{*}{$\stackrel{0}{\frac{\pi}{5}}$} & No. of pump & \multicolumn{2}{|c|}{4} & \multicolumn{2}{|c|}{6} \\
\hline & $\operatorname{Flow}\left(m^{3} / h\right)$ & \multicolumn{2}{|c|}{64} & \multicolumn{2}{|c|}{120} \\
\hline & $\operatorname{Head}(m)$ & \multicolumn{2}{|c|}{68} & \multicolumn{2}{|c|}{60} \\
\hline & $\mathrm{Hp}(\mathrm{kw})$ & \multicolumn{2}{|c|}{$24.7(18.5)$} & \multicolumn{2}{|c|}{$40(30)$} \\
\hline & Spray/ time operation (min). & \multicolumn{2}{|c|}{15} & \multicolumn{2}{|c|}{$5-12$} \\
\hline$\sum_{0}^{\infty} \frac{\pi}{\pi}$ & $\begin{array}{c}\text { *Pcs.drip (Rate of flow in } \mathrm{L} / \mathrm{h} \times \text { Operation } \\
\text { time in } \mathrm{min} \text { ) }\end{array}$ & \multicolumn{2}{|c|}{$8 \times 30$} & \multicolumn{2}{|c|}{$8 \times 30$ and $4 \times 60$} \\
\hline 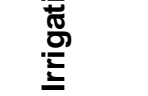 & $\begin{array}{c}{ }^{*} \text { Npcs.drip (Rate of flow in } \mathrm{L} / \mathrm{h} \times \text { Opera- } \\
\text { tion time in } \mathrm{min} \text { ) }\end{array}$ & \multicolumn{2}{|c|}{$4 \times 30$} & \multicolumn{2}{|c|}{---} \\
\hline$\Phi$ & Domestic water & \multirow{2}{*}{\multicolumn{2}{|c|}{$\sqrt{ }$}} & \multirow{2}{*}{\multicolumn{2}{|c|}{$\begin{array}{l}\sqrt{l}-1 \\
\sqrt{ }\end{array}$}} \\
\hline$\sum^{\pi} \bar{g}$ & Treated wastewater & & & & \\
\hline & Manual & \multicolumn{2}{|c|}{---} & \multicolumn{2}{|c|}{--} \\
\hline$\frac{5}{\sigma}$ & Automatic & \multicolumn{2}{|c|}{$\sqrt{ }$} & \multicolumn{2}{|c|}{---} \\
\hline$\sum^{\frac{5}{\pi}} \frac{0}{0}$ & Central control & \multicolumn{2}{|c|}{---} & \multicolumn{2}{|c|}{$\sqrt{ }$} \\
\hline \multirow{5}{*}{ 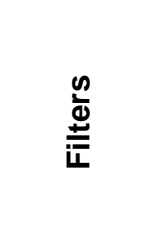 } & \multirow{2}{*}{ Type } & Screen & Media & Screen & Media \\
\hline & & $\sqrt{ }$ & --- & $\sqrt{ }$ & $\sqrt{ }$ \\
\hline & Number & 2 & --- & 4 & 4 \\
\hline & Inlet/Outlet(inch) & $10 / 10$ & --- & $4 / 4$ & $4 / 4$ \\
\hline & Flow rate $\left(m^{3} / h\right) /$ one filter & 300 & --- & 50 & 50 \\
\hline
\end{tabular}

Table 3. Actual site conditions under investigation

${ }^{*}$ Pcs.drip (Self compensating drip). $\quad{ }^{* *} N p c s$.drip (Non self-compensating drip). 
Table 4. Analysis of the total cations and anions and phosphorus in domestic water and treated wastewater sample in Eastown and Lake View sites

\begin{tabular}{|c|c|c|c|c|c|c|}
\hline \multirow[b]{2}{*}{ Parameter } & \multirow[b]{2}{*}{ Sites } & \multirow[b]{2}{*}{$\begin{array}{c}\text { Domestic } \\
\text { water }\end{array}$} & \multirow[b]{2}{*}{$\begin{array}{c}\text { Treated } \\
\text { wastewater }\end{array}$} & \multicolumn{3}{|c|}{$\begin{array}{c}\text { Allowable limit of using treated } \\
\text { wastewater }\end{array}$} \\
\hline & & & & None & $\begin{array}{l}\text { Slight to } \\
\text { moderate }\end{array}$ & Severe \\
\hline $\mathrm{pH}$ & $\begin{array}{l}\text { Eastown } \\
\text { Lake view }\end{array}$ & $\begin{array}{c}6.5 \\
7\end{array}$ & $\begin{array}{l}6.55 \\
8.07\end{array}$ & --- & $6.5-8.4$ & 5 \\
\hline $\begin{array}{l}\text { Electrical conductivity } \\
\text { (EC), dS/m }\end{array}$ & $\begin{array}{l}\text { Eastown } \\
\text { Lake view }\end{array}$ & $\begin{array}{c}0.35 \\
0.3\end{array}$ & $\begin{array}{l}0.86 \\
1.37\end{array}$ & $<0.7$ & $0.7-3.0$ & $>3.0$ \\
\hline $\begin{array}{l}\text { Total dissolved solids } \\
\text { (TDS), mg/L }\end{array}$ & $\begin{array}{l}\text { Eastown } \\
\text { Lake view }\end{array}$ & $\begin{array}{l}224 \\
192\end{array}$ & $\begin{array}{l}550.4 \\
876.8\end{array}$ & $<450$ & $450-2000$ & $>2000$ \\
\hline $\mathrm{Ca}^{2+}, \mathrm{mg} / \mathrm{L}$ & $\begin{array}{l}\text { Eastown } \\
\text { Lake view }\end{array}$ & $\begin{array}{l}0.002 \\
0.001\end{array}$ & $\begin{array}{l}0.0027 \\
0.0027\end{array}$ & --- & --- & --- \\
\hline $\mathrm{Mg}^{2+}, \mathrm{mg} / \mathrm{L}$ & $\begin{array}{c}\text { Eastown } \\
\text { Lake view }\end{array}$ & $\begin{array}{c}0.25 \\
0.2 \\
\end{array}$ & $\begin{array}{l}0.3755 \\
0.376\end{array}$ & - & - & - \\
\hline $\mathrm{Na}^{+}, \mathrm{mg} / \mathrm{L}$ & $\begin{array}{l}\text { Eastown } \\
\text { Lake view }\end{array}$ & $\begin{array}{l}0.25 \\
0.28\end{array}$ & $\begin{array}{l}0.3559 \\
0.4229\end{array}$ & $<69$ & $69-207$ & $>207$ \\
\hline $\mathrm{K}^{+}, \mathrm{mg} / \mathrm{L}$ & $\begin{array}{l}\text { Eastown } \\
\text { Lake view }\end{array}$ & $\begin{array}{l}18 \\
12\end{array}$ & $\begin{array}{l}21.85 \\
23.88\end{array}$ & --- & --- & --- \\
\hline $\mathrm{Co3}^{=}, \mathrm{mg} / \mathrm{L}$ & $\begin{array}{l}\text { Eastown } \\
\text { Lake view }\end{array}$ & $\begin{array}{l}0 \\
0\end{array}$ & $\begin{array}{l}0 \\
0\end{array}$ & --- & --- & --- \\
\hline $\mathrm{HCO}_{3}{ }^{-}, \mathrm{mg} / \mathrm{L}$ & $\begin{array}{c}\text { Eastown } \\
\text { Lake view }\end{array}$ & $\begin{array}{l}20 \\
10 \\
\end{array}$ & $\begin{array}{l}24.4 \\
30.5 \\
\end{array}$ & $<91.5$ & $\begin{array}{l}91.5- \\
518.5\end{array}$ & $>518.5$ \\
\hline So4=, mg/L & $\begin{array}{l}\text { Eastown } \\
\text { Lake view }\end{array}$ & $\begin{array}{l}30 \\
50\end{array}$ & $\begin{array}{l}307.2 \\
249.6\end{array}$ & --- & --- & --- \\
\hline $\mathrm{Cl}^{-}, \mathrm{mg} / \mathrm{L}$ & $\begin{array}{l}\text { Eastown } \\
\text { Lake view }\end{array}$ & $\begin{array}{l}15 \\
57\end{array}$ & $\begin{array}{l}36.9 \\
248\end{array}$ & $\begin{array}{c}< \\
106.5\end{array}$ & $106.5-350$ & $>350$ \\
\hline$p, m g / L$ & $\begin{array}{l}\text { Eastown } \\
\text { Lake view }\end{array}$ & $\begin{array}{l}0.9 \\
1,2\end{array}$ & $\begin{array}{l}4.557 \\
4.639\end{array}$ & --- & --- & --- \\
\hline
\end{tabular}

Table 5. Analysis of heavy metals in treated wastewater sample in Eastown and Lake View sites

\begin{tabular}{|c|c|c|c|}
\hline Parameter & Sites & $\begin{array}{l}\text { Water } \\
\text { source }\end{array}$ & $\begin{array}{c}\text { Max. Allowed Heavy } \\
\text { Metals Mg/L }\end{array}$ \\
\hline $\mathrm{Al}, \mathrm{mg} / \mathrm{L}$ & $\begin{array}{l}\text { Eastown } \\
\text { Lake view }\end{array}$ & $\begin{array}{l}0.0631 \\
0.0633\end{array}$ & 5 \\
\hline $\mathrm{B}, \mathrm{mg} / \mathrm{L}$ & $\begin{array}{l}\text { Eastown } \\
\text { Lake view }\end{array}$ & $\begin{array}{l}0.0859 \\
0.0783\end{array}$ & --- \\
\hline $\mathrm{Cr}, \mathrm{mg} / \mathrm{L}$ & $\begin{array}{l}\text { Eastown } \\
\text { Lake view }\end{array}$ & $\begin{array}{l}0.0372 \\
0.0529\end{array}$ & 0.1 \\
\hline $\mathrm{Fe}, \mathrm{mg} / \mathrm{L}$ & $\begin{array}{l}\text { Eastown } \\
\text { Lake view }\end{array}$ & $\begin{array}{l}0.1267 \\
0.1284\end{array}$ & 5 \\
\hline $\mathrm{Mn}, \mathrm{mg} / \mathrm{L}$ & $\begin{array}{l}\text { Eastown } \\
\text { Lake view }\end{array}$ & $\begin{array}{l}0.1655 \\
0.1547\end{array}$ & 0.2 \\
\hline $\mathrm{Ni}, \mathrm{mg} / \mathrm{L}$ & $\begin{array}{l}\text { Eastown } \\
\text { Lake view }\end{array}$ & $\begin{array}{l}0.0501 \\
0.0486\end{array}$ & 0.2 \\
\hline $\mathrm{Pb}, \mathrm{mg} / \mathrm{L}$ & $\begin{array}{l}\text { Eastown } \\
\text { Lake view }\end{array}$ & $\begin{array}{l}0.2288 \\
0.2309\end{array}$ & 5 \\
\hline $\mathrm{Zn}, \mathrm{mg} / \mathrm{L}$ & $\begin{array}{l}\text { Eastown } \\
\text { Lake view }\end{array}$ & $\begin{array}{l}0.0111 \\
0.0178\end{array}$ & 2 \\
\hline
\end{tabular}


Table 6. Average climatic data in Lake View and Eastown sites

\begin{tabular}{|c|c|c|c|c|c|c|c|c|c|c|c|c|}
\hline Month & Jan & Feb & Mar & Apr & May & Jun & Jul & Aug & Sep & Oct & Nov & Dec \\
\hline$U_{\text {mean }}(\mathrm{m} / \mathrm{s})$ & 0.3 & 0.3 & 0.6 & 0.6 & 0.6 & 0.6 & 0.6 & 0.6 & 0.7 & 0.5 & 0.3 & 0.2 \\
$T_{\min }\left({ }^{\circ} \mathrm{C}\right)$ & 11 & 10 & 10 & 10.2 & 12.8 & 21.5 & 23.1 & 22.1 & 19.6 & 14.9 & 12 & 13.8 \\
$T_{\max }\left({ }^{\circ} \mathrm{C}\right)$ & 24.9 & 32.5 & 30.3 & 35 & 39 & 39.5 & 40 & 40 & 38 & 36.5 & 32.9 & 19.7 \\
$R H_{\text {mean }(\%)}$ & 50.9 & 56.8 & 55.3 & 48.4 & 38.3 & 50.4 & 52.8 & 53.9 & 57.6 & 58.6 & 57.8 & 64.7 \\
Eto (mm/day) & 1.3 & 1.7 & 2.6 & 3.5 & 4.4 & 4.5 & 4.6 & 4.4 & 3.6 & 2.5 & 1.9 & 1.5 \\
\hline
\end{tabular}

Umean: Mean value of wind speed; $T_{\min }$ : Minimum value of temperature; $T_{\max }$ : Maximum value of temperature; $R H_{\text {mean }}$ : Mean value of relative humidity.

Table 7. Rating of Lower Quarter Distribution Uniformity (DULQ) for Sprays.

\begin{tabular}{|l|c|}
\hline Classification & Uniformity, CU \%. \\
\hline Excellent & $75 \%$ \\
Very good & $65 \%$ \\
Good & $55 \%$ \\
Fair & $50 \%$ \\
Poor & $40 \%$ \\
\hline
\end{tabular}

\section{Plant Water Requirement}

Costello et al (1993) derived plant water requirement on $\mathrm{ET}_{\mathrm{o}}$ as a reference for a cool-season grass species with a specified height (typically 7-15 $\mathrm{cm}$ tall) under particular growing conditions, this reference must be adjusted to better fit the plant water requirement of a specific plant species in the landscape setting. The landscape coefficient $\mathrm{K}_{\mathrm{L}}$ was used to adjust $E T_{0}$ to determine the plant water requirement (PWR) of a specific plant species:

$$
P W R=E T_{o} \times K_{L} \ldots \ldots \ldots \ldots \ldots \text { (4) }
$$

Where

PWR = Plant water requirement (in. or $\mathrm{mm} /$ period). $\mathrm{ET}_{\mathrm{O}}=$ Reference $\mathrm{ET}$ based on cool-season grass (in. or $\mathrm{mm}$ /period).

$\mathrm{K}_{\mathrm{L}}=$ Landscape coefficient (dimensionless).

A landscape coefficient $\mathrm{KL}$ was suggested by Awady et al (2003) and IA (2005), it can be calculated according to the following formula:

$$
K_{L}=K_{s} \times K_{m c} \times K_{d}
$$

\section{Where:}

$\mathrm{K}_{\mathrm{L}}=$ Landscape coefficient (dimensionless).

$\mathrm{K}_{\mathrm{s}}=$ Adjustment factor representing characteristics for a particular plant species (dimensionless).

$\mathrm{K}_{\mathrm{mc}}=$ Adjustment factor for microclimate influences upon the planting (dimensionless).

$\mathrm{K}_{\mathrm{d}}=$ Adjustment factor for plant density (dimensionless).

Table 8. Species Factor (Ks) for different Plant Types

\begin{tabular}{|l|l|l|l|}
\hline Vegetation & High & Average & Low \\
\hline Warm season turfgrass & ----- & $\mathbf{0 . 6}$ & ---- \\
Cool Season Turfgrass & ----- & $\mathbf{0 . 8}$ & ---- \\
\hline
\end{tabular}

Awady et al (2003) and IA (2009).

Table 9. Microclimate Factor (Kmc) for different Plant Types

\begin{tabular}{|l|l|l|l|}
\hline Vegetation & High & Average & Low \\
\hline Turfgrass & 1.2 & 1 & 0.8 \\
\hline
\end{tabular}

Awady et al (2003) and IA (2009).

Table 10. Density Factor (Kd) for different Plant Types.

\begin{tabular}{|l|l|l|l|}
\hline Vegetation & High & Average & Low \\
\hline Turfgrass & 1 & 1 & 0.6 \\
\hline
\end{tabular}

Awady et al (2003) and IA (2009). 


\section{Filtration efficiency}

(El-Tantawy, 2006) It was calculated using the following equations:

$$
\left(E_{f}\right)=\left(S_{s}-S_{i} / S_{s}\right) * 100
$$

\section{Where}

$E_{f}=$ Filtration efficiency, \%.

Ss $=$ The sediment's concentration in the entrance of water, mg./L.

$\mathrm{Si}=$ The sediment's concentration in the filtered water, mg./L.

\section{Quality index}

Table 11. Indicates turf quality index and represents color, density, and ground cover percent for lawn plant (paspalum 10)

\begin{tabular}{|c|c|c|c|}
\hline Type of turf & Color & $\begin{array}{c}\text { Density } \\
\text { (pcs/ }^{2} \text { ) }\end{array}$ & $\begin{array}{c}\text { Ground } \\
\text { cover\% }\end{array}$ \\
\hline Paspalum 10 & $0-9$ & $0-9$ & $1-9$ \\
\hline
\end{tabular}

Khaseeva, 2013

- Color: a 0-to-9 scale, where 0 = brown, (dead turf); 6 =Acceptable quality for home lawn; and 9 = optimum color (dark green)

- Density (pcs $\left./ \mathrm{m}^{2}\right)$ : summer density (1=low, $9=$ high), turf density was measured instrumentally and expressed in number of tillers per unit area $\left(\mathrm{pcs} / \mathrm{m}^{2}\right)$, high ratings $(>10000$ shoots per sq. $\mathrm{m}$ ), 9 provided moderate density (6000 to 10000 shoots per sq. $\mathrm{m}$ ) and 4 demonstrated low ratings ( $<6000$ shoots per sq.m),

- Ground cover\%: ground cover $(1=0 \%, 9=100 \%$ cover).

\section{RESULTS AND DISCUSSION}

Laboratory analysis of total suspended solids in wastewater for Eastown and Lake View sites:

Data presented in Table 12 showed that the analysis of total suspended solids in wastewater for Eastown and Lake View sites before and after filters.

Data indicated that the concentration of total suspended solids less by (93.6 and $97.9 \%$ ) with manual and automatic operation, respectively in
Lake view site and less by (50 and $60 \%$ ) with manual and automatic operation, respectively in Eastown site. This means that the efficient impurity removal is higher in Lake view site than Eastown site. This is due to the use media filters with screen filters in Lake View site and media filters only in Eastown site.

Table 12. Analysis of TSS of wastewater samples before and after each filter in Eastown and Lake view sites.

\begin{tabular}{|c|c|c|c|}
\hline & $\begin{array}{l}\text { Water } \\
\text { source } \\
\text { (before } \\
\text { filters) }\end{array}$ & $\begin{array}{l}\text { After } \\
\text { media } \\
\text { filters }\end{array}$ & $\begin{array}{l}\text { After } \\
\text { screen } \\
\text { filters }\end{array}$ \\
\hline Manual operation & 140 & 37 & 9 \\
\hline 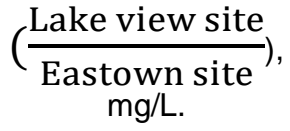 & 80 & - & $\overline{40}$ \\
\hline Automatic operation & 140 & 23 & 3 \\
\hline 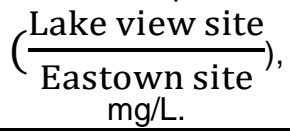 & 80 & - & $\overline{32}$ \\
\hline
\end{tabular}

Laboratory analysis of dirtiness in filter in Eastown and Lake View sites

Data presented in Table 13 showed that the analysis of dirtiness in filter. The ranges of the particle size were determined in three different classes, i.e. $>0.05 \mathrm{~mm}, 0.05-0.002 \mathrm{~mm}$, and $<0.002 \mathrm{~mm}$. The result showed that the clay ratio in dirtiness were highest by (5.27 and $21.06 \%$ ) compared to sand and silt, respectively, in Lake view site, and (11.63 and $21.27 \%$ ) compared to sand and silt, respectively, in Eastown site.

It is clear from that the ratio of clay was (42.11 and $44.3 \%$ ) in Lake view site and Eastown site, respectively, and will cause clogging in filters so it need to backwashing the filters every ( 2 and $1.5 \mathrm{~h}$ ) in Lake view site and Eastown site, respectively, to get rid of dirtiness.

Table 13. Mechanical analysis of dirtiness in filter in Eastown and Lake View sites.

\begin{tabular}{|c|c|c|c|}
\hline Particle size & Sand & Silt & Clay \\
\hline Distribution, & $>0.05 \mathrm{~mm}$ & $0.05-0.002$ & $<0.002$ \\
$\mathrm{~mm}$ & & $\mathrm{~mm}$ & $\mathrm{~mm}$ \\
Lake view, \% & 36.84 & 21.05 & 42.11 \\
Eastown, \% & 32.67 & 23.03 & 44.3 \\
\hline
\end{tabular}




\section{Water inflow to the sites}

Fig. 5 showed a graph for water inflow to the Eastown and Lake View sites. The result showed that the maximum inflow occurred in Summer compared with other seasons, which was $15.89 \mathrm{~mm} / \mathrm{d}$ in Eastown site and was $8.75 \mathrm{~mm} / \mathrm{d}$ in Lake view site, and the amount of water used in Eastown site was highest by $44.9 \%$ compared to Lake View site, which is due to the bad management of the water distribution and the lack of continuous maintenance in Eastown site.

\section{Irrigation water requirement in different sites}

Data presented in Fig. 6 Showed the irrigation water requirements among different months of the growing seasons for turf in Eastown and Lake View sites.

Data indicated that the highest values of water requirements were in summer especially in July which was $61.603 \mathrm{~mm} / \mathrm{month}$, in Eastown site, and was $154.008 \mathrm{~mm} / \mathrm{month}$, in Lake view site. This be tribute to the high value of evaporation in summer compared to other season and the difference in the amount of water between the two sites is due to the age of turf which is two years, in Lakeview site, and five months in Eastown site, so it need a large amount of water in Lake view site compared to Eastown site as classified by Awady et al (2003) and IA (2009) and extracted from tables (8, 9 and $10)$ in the "Materials and Methods" section.

\section{Emission uniformity (EU) for drip system}

Fig. 7 described emission uniformity (EU) by using domestic and treated wastewater with manual and automatic operation for Lake View and Eastown sites. Manual operation occur when pressure loss before and after filters was 0.5 bar and in automatic operation the pressure loss is adjusted before and after filters by backflushing controller and differential pressure and when pressure loss become 0.5 bar washing done automatic for each unit of filters, so the efficiency of automatic operation is better than the efficiency of manual operation.

Emission uniformity was (89.2 - 91.5 - 88 - 90) $\%$ for on-line, and built-in emitters in Eastown site, on-line, and built-in emitters in Lakeview site, respectively, for domestic water with manual operation and was (94.5 - 96.6- 93 - 95) \% for on-line, and built-in emitters in Eastown site, on-line, and built-in emitters in Lakeview site, respectively, for domestic water with automatic operation, while it

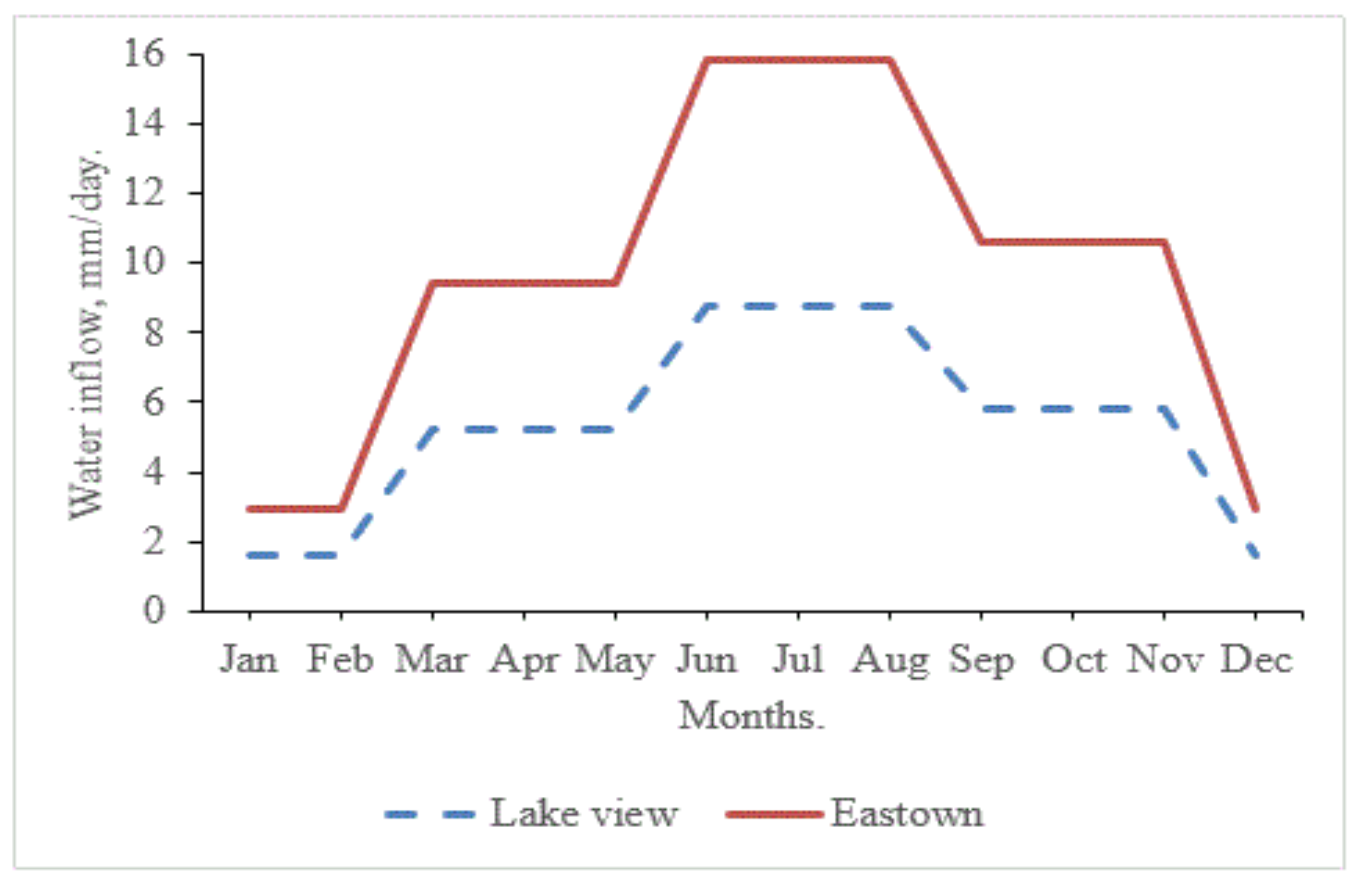

Fig. 5. Water inflow to Eastown and Lake View sites. 


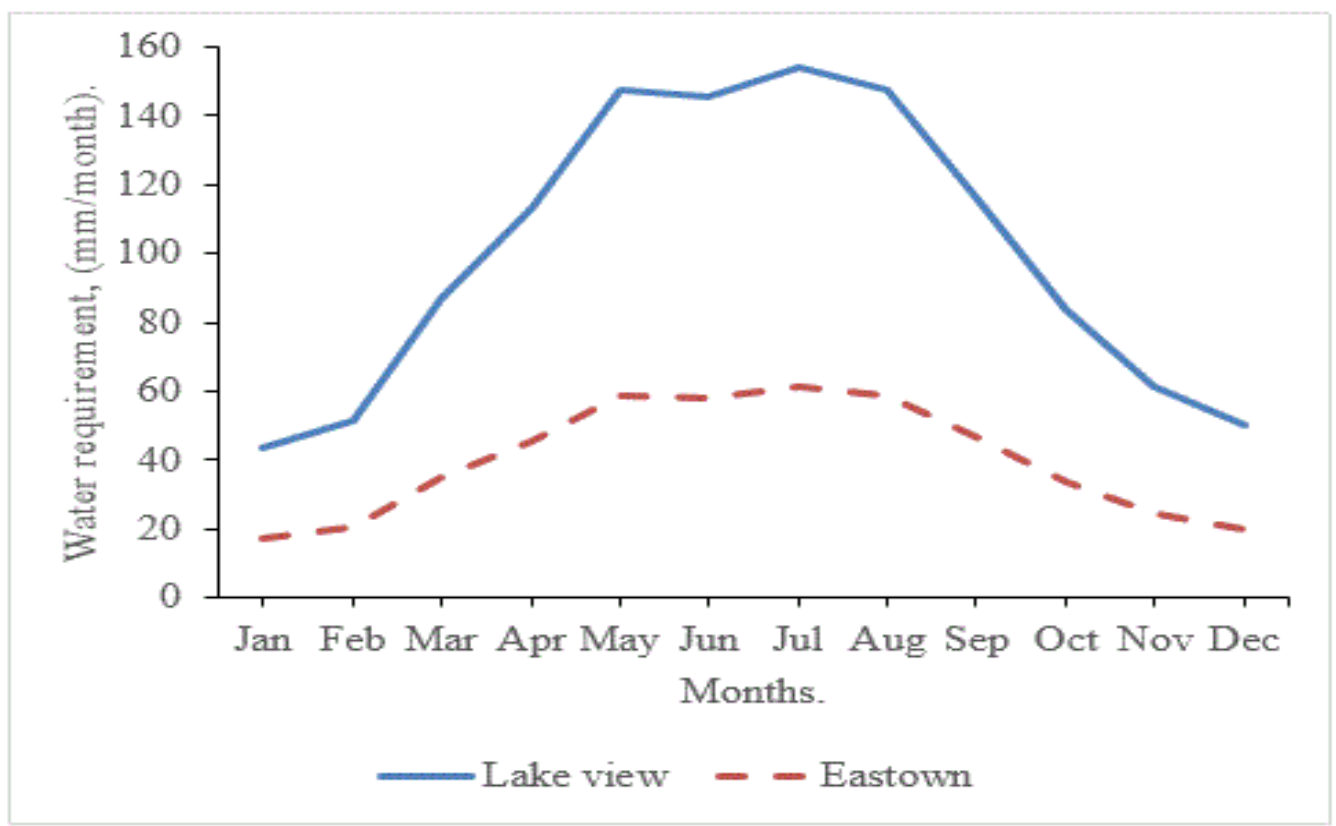

Fig. 6. Irrigation water requirement for Eastown and Lake View sites

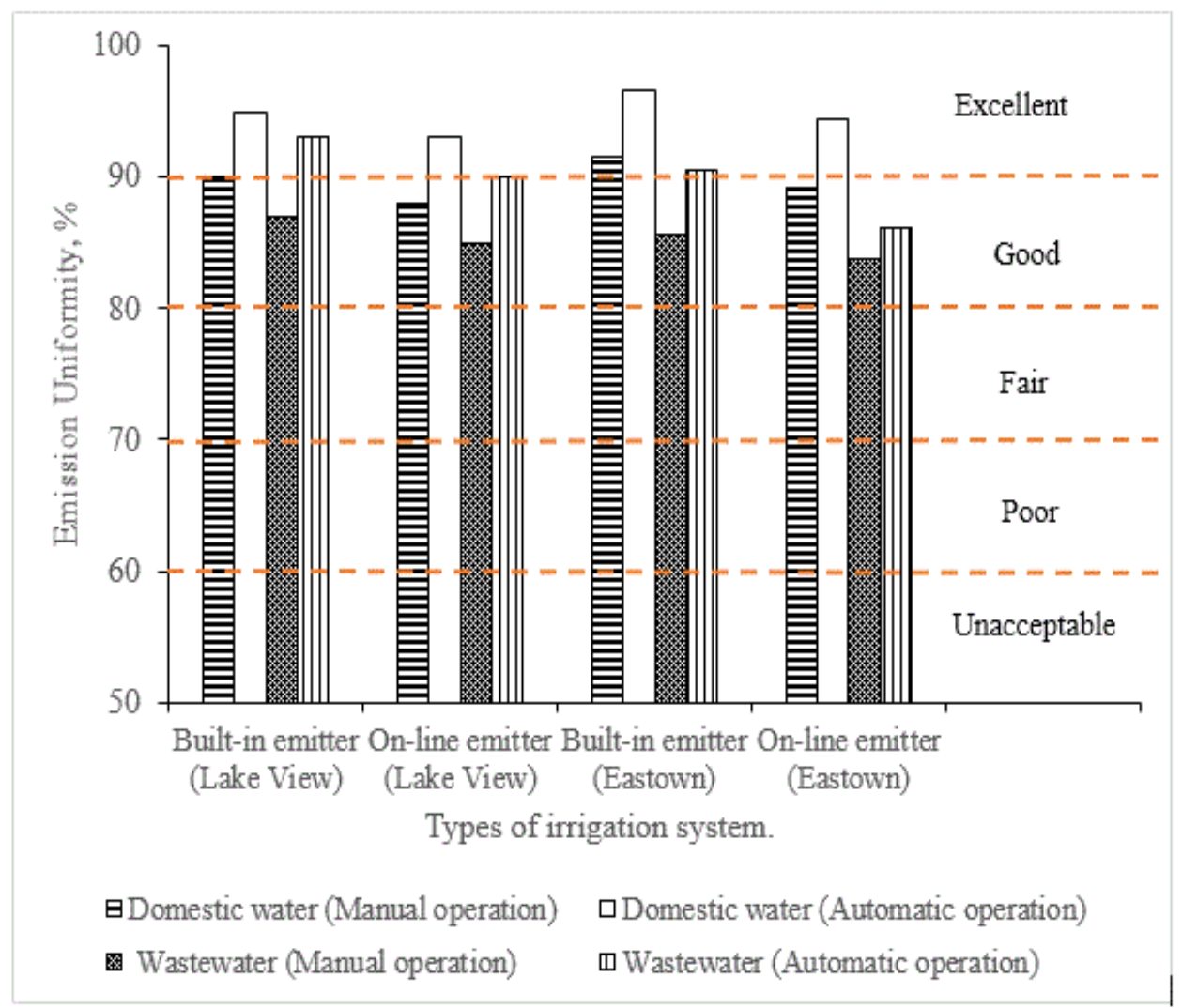

Fig. 7. Emission uniformity for drip system by using treated wastewater and domestic water for Eastown and Lake view sites. 
was (83.8 - 85.6 - 85 - 87) \% for on-line, and builtin emitters in Eastown site, on-line, and built-in emitters in Lakeview site, respectively, for treated wastewater with manual operation and was (86.1 90.5 - 90 - 93) \% for on-line, built-in emitters in Eastown site, on-line, and built-in emitters in Lakeview site, respectively, for treated wastewater with automatic operation.

The results showed that the emission uniformity was higher in automatic operation than manual operation, this is due to the time consumed between two excessive backwashing process in automatic operation is less than the time consumed between two excessive backwashing process in manual operation, so it effects on clogging in emitters and network, and emission uniformity was higher in domestic water than wastewater, this due to total suspended solids in wastewater.

\section{Distribution Uniformity (DU) for spray system}

Fig. 8 described the distribution uniformity (DU) by using domestic and treated wastewater with manual and automatic operation for Lake View and Eastown.

In Eastown site, distribution uniformity for wastewater was (67.3 and $72.4 \%$ ) for manual and automatic operation, respectively, while for domestic water was (74.1 and $79 \%)$ for manual and automatic operation, respectively.

In Lake View site, distribution uniformity for wastewater was (70 and 75\%) for manual and automatic operation, respectively; while for domestic water was (73 and $78 \%$ ) for manual and automatic operation, respectively.

The results showed that distribution uniformity was higher in automatic operation than manual operation, this is due to the time consumed between two excessive backwashing process in automatic operation is less than the time consumed between two excessive backwashing process in manual operation, so it effects on clogging in network and distribution uniformity was higher in domestic water than wastewater, which is due to total suspended solids in wastewater.

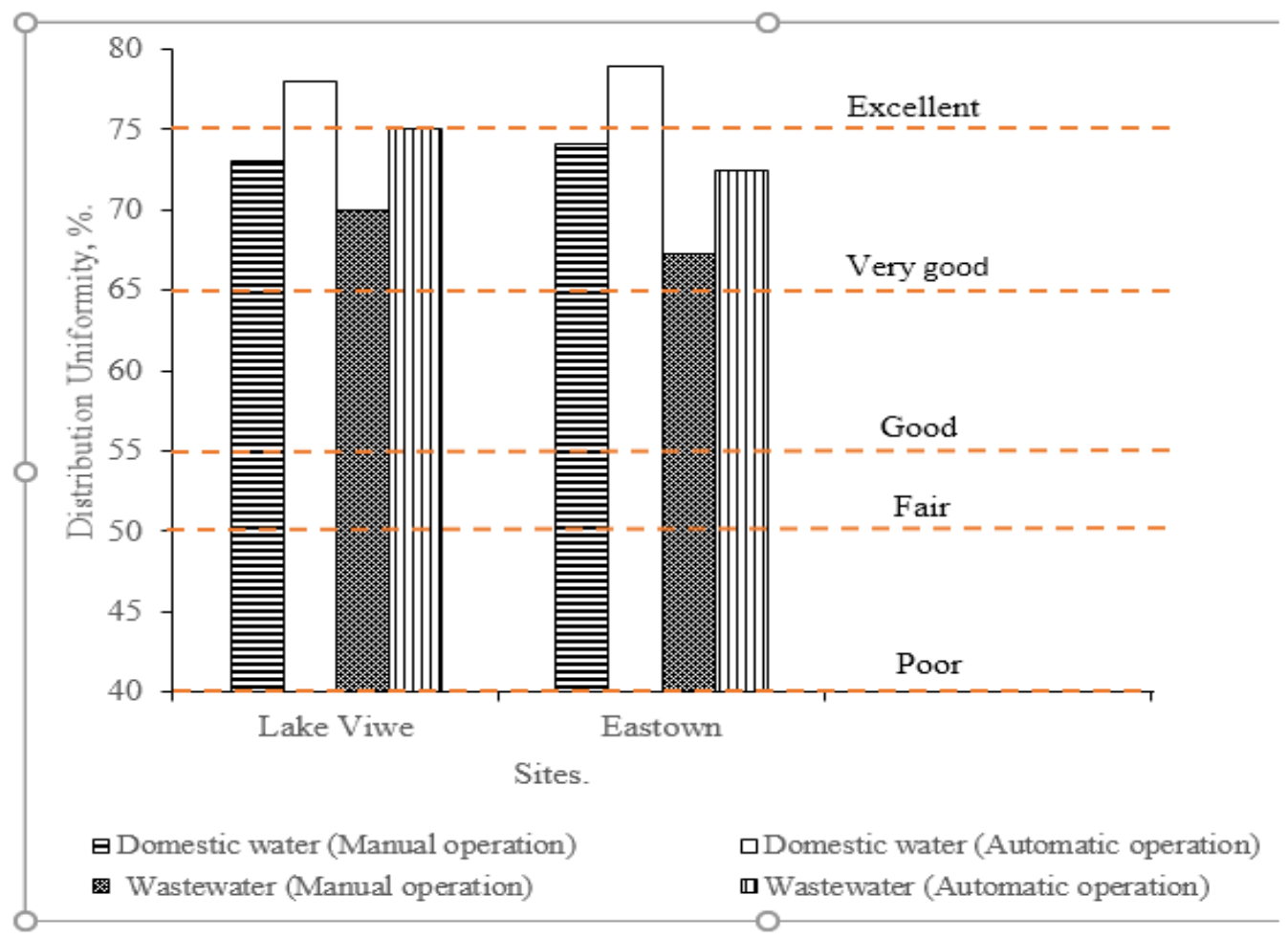

Fig. 8. Distribution uniformity for spray system by using treated wastewater and domestic water for Lake View and Eastown sites. 
Affect of domestic and wastewater on clogging ratio of emitters in different sites

The clogging ratio of emitters used was calculated after five months for Eastown site and after two years for Lake View site. The results, as shown in Figs. 9 and 10, illustrated that, the clogging rate of emitters under screen filters in Eastown site was larger than media and screens filters in Lake view site, Also the clogging ratio by using treated wastewater was higher than using domestic water, which is due to the total suspended solids in wastewater and clogging ratio increased with increasing the time of installation of the emitter and lack in maintenance. The clogging of emitters was physical and higher at the end of drip line than the beginning dripline.

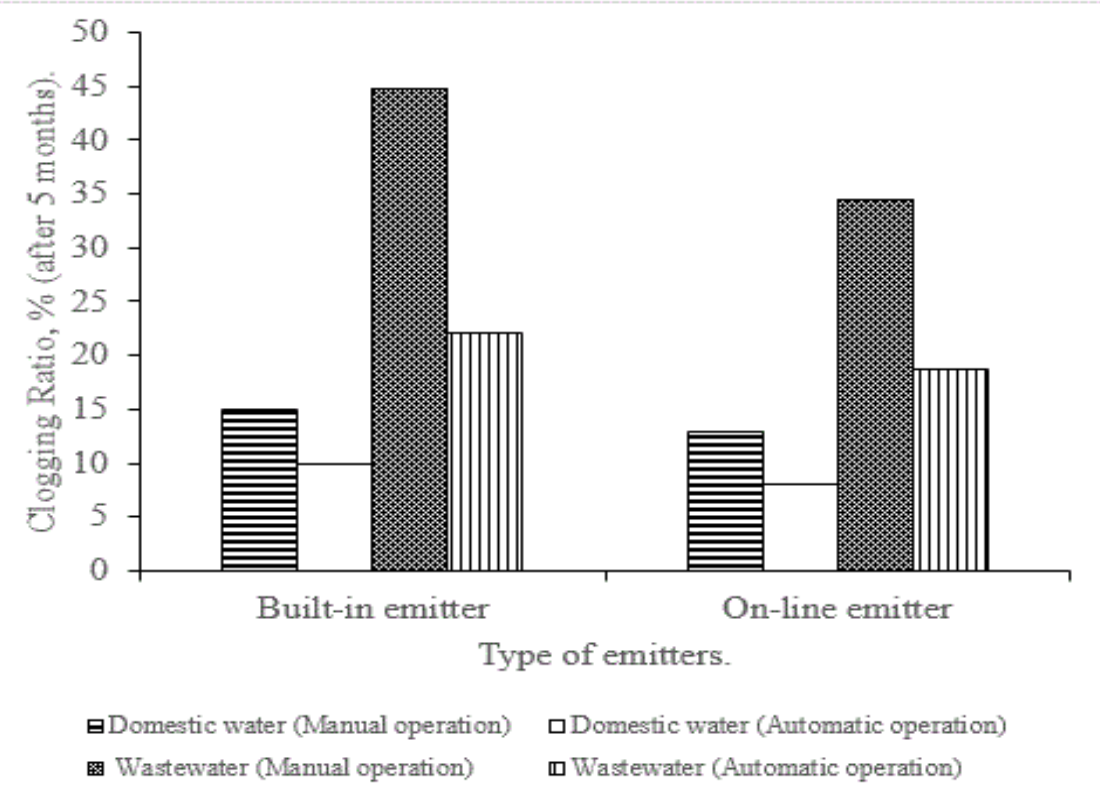

Fig. 9. Effect of domestic and wastewater in emitter clogging for Eastown site.

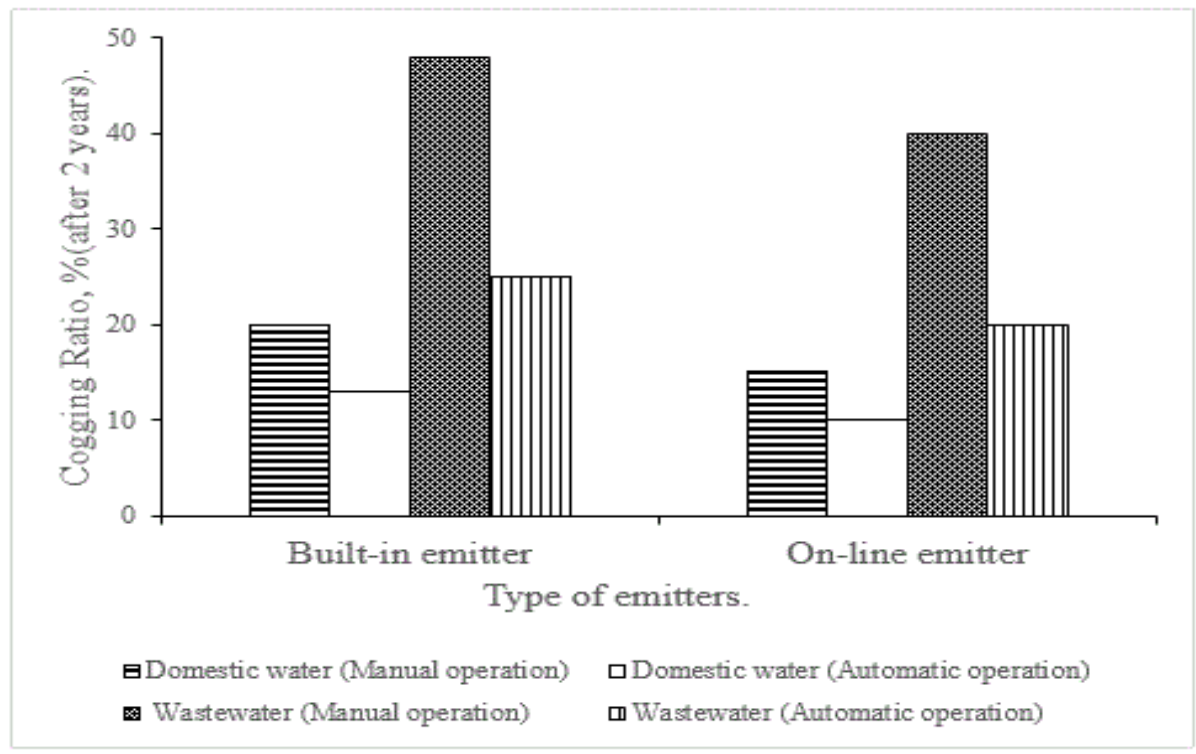

Fig. 10. Effect of domestic and wastewater in emitter clogging for Lake view site. 
Filtration efficiency for Eastown and Lake View sites

Data presented in Fig. 11 show the filtration efficiency in Lake view and Eastown sites, under manual and automatic operation for screen and media filters.

The results showed that, the efficiency of filtration was increased with domestic water than wastewater for automatic operation than manual operation, this is due to manual operation occur, when pressure loss before and after filters was 0.5 bar and in automatic operation the pressure loss is adjusted before and after filters by backflushing controller and differential pressure and when pressure loss become 0.5 bar washing done automatic for each unit of filters. Also, screen filters were more efficient in Lake view than screen filters in Eastown with wastewater. This is due to the media filters with screen filters in Lake view with a larger filtration area.

\section{Effect of domestic and wastewater used on turf quality index}

From Figs. 12 and 13, the results showed that, the turf quality index (color, density, ground cover $\%)$ gave a higher degree with treated wastewater than domestic water, due to nutrients in treated wastewater and gave a higher degree in Lake view site than Eastown site. This is due to the management operation which used central control irrigation management operation system in Lake view site and automatic irrigation management operation system in Eastown site, this gave a good appearance and quality compared with Eastown site, as classified by Khaseeva, 2013 and extracted from Table (9) in the "Materials and Methods" section.

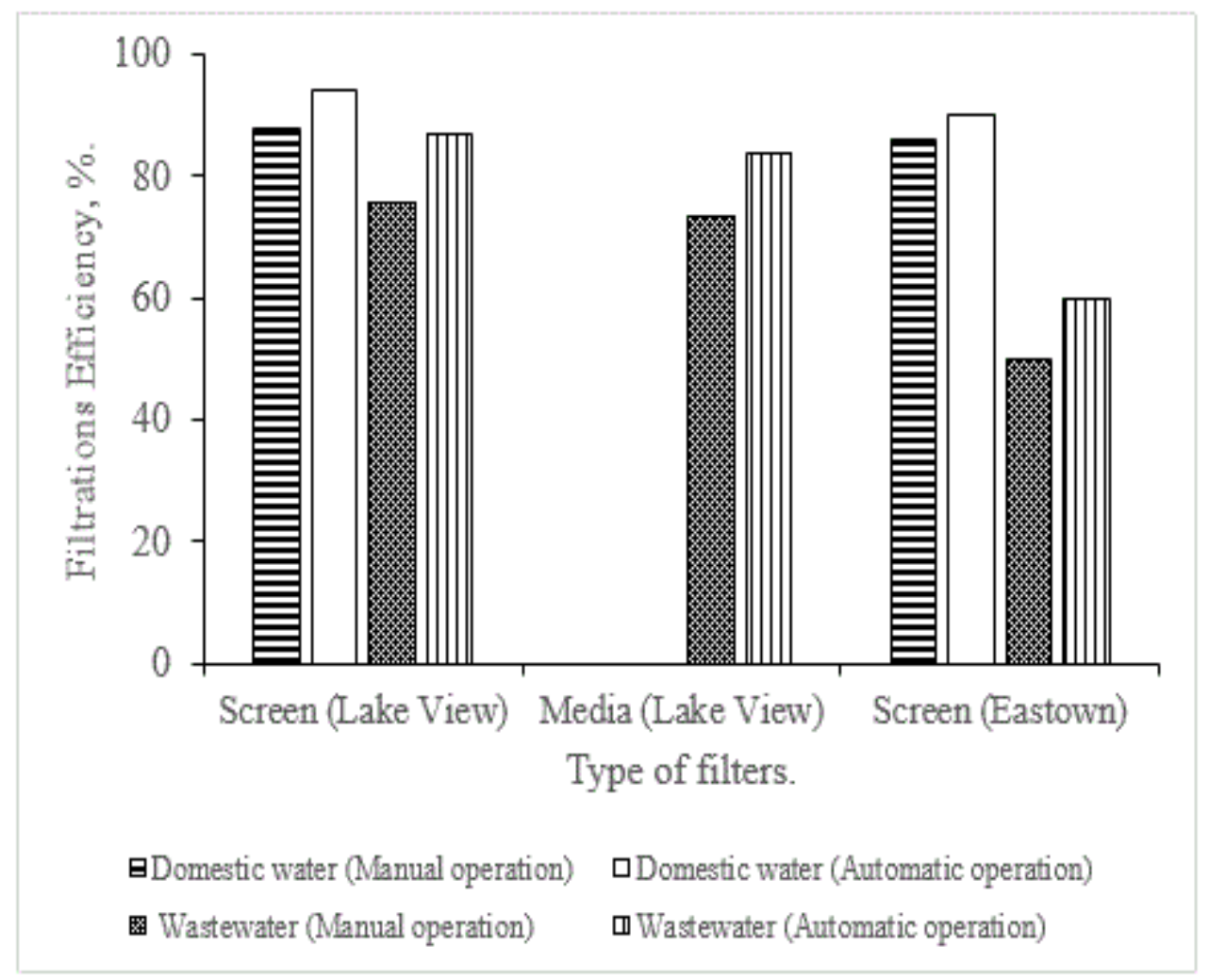

Fig. 11. The effect of filters on the Filtration Efficiency. 


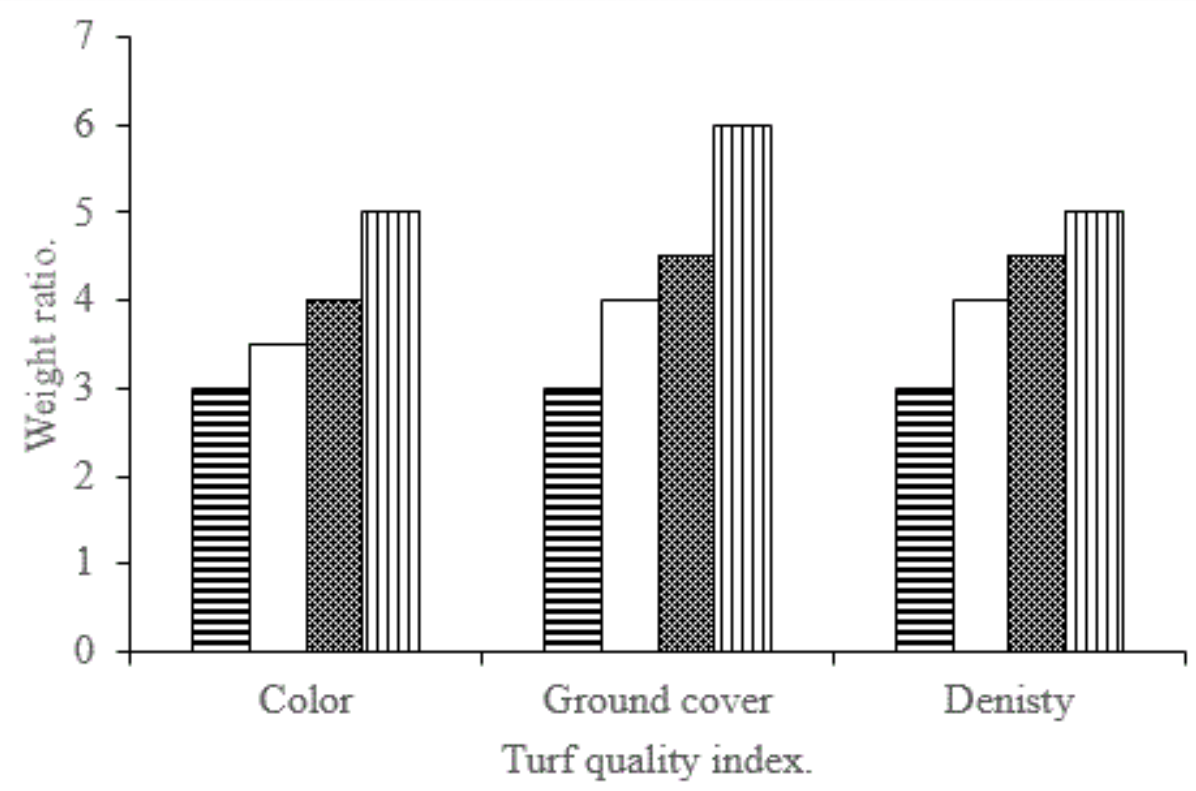
日Domestic water (Manual operation)
$\square$ Domestic water (Automatic operation)
ه Wastewater (Manual operation)
๓ Wastewater (Automatic operation)

Fig. 12. Effect of domestic and wastewater used on turf quality index for Eastown site.

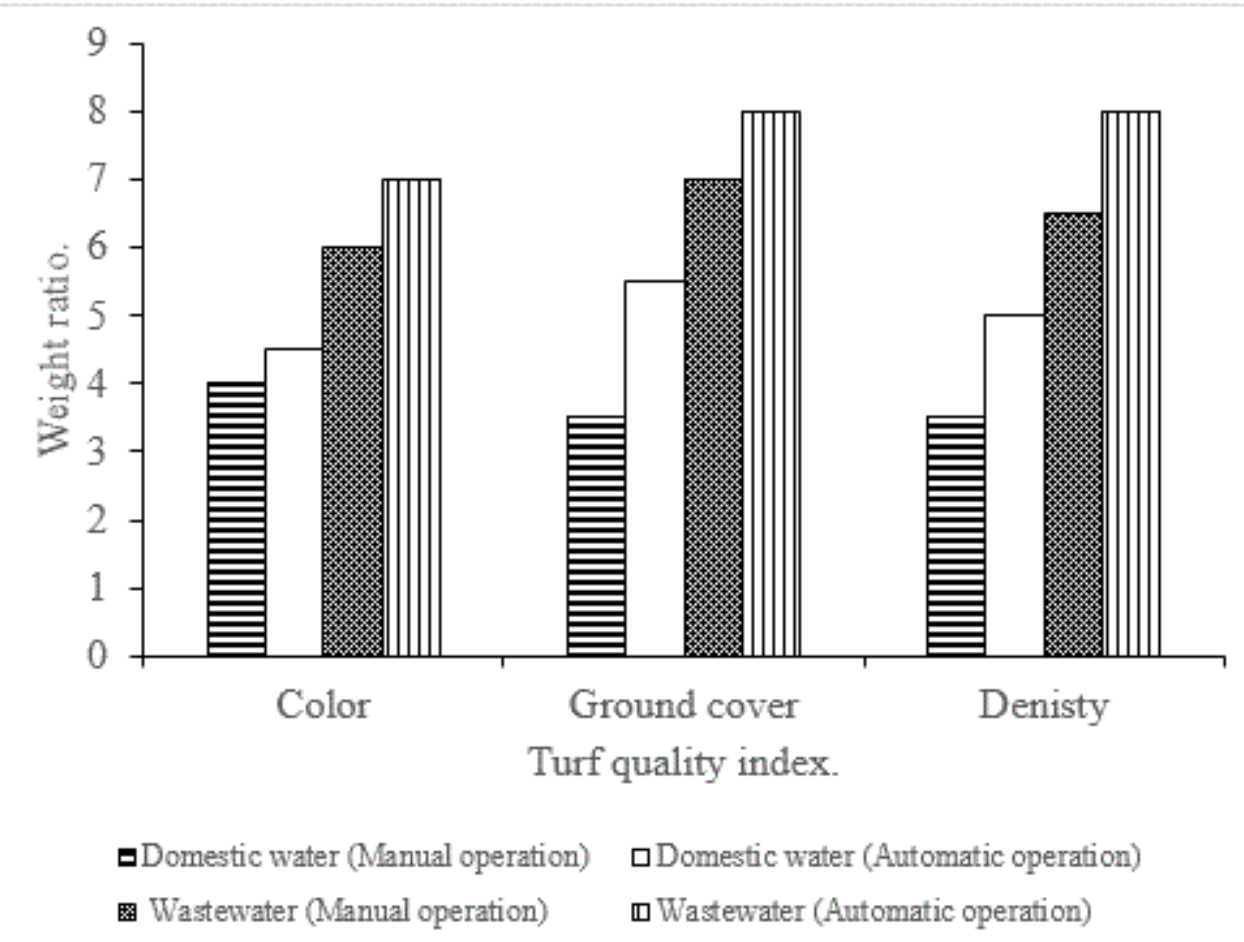

Fig. 13. Effect of domestic and wastewater used on turf quality index for Lake view site. 


\section{CONCLUSION}

The results strongly indicated the effect of wastewater on the performance of irrigation system through the following marks:

1-Screen and media filter both with treated wastewater are much better (filtration efficiency) than screen filter alone.

2-Clogging was higher when using treated wastewater than domestic water and with manual operation than automatic operation.

3- Emission uniformity for drip system was higher when using automatic operation than manual operation and with domestic water than wastewater.

4- Distribution uniformity for spray system was higher when using automatic operation than manual operation and with domestic water than wastewater.

5- The concentration of total suspended solids less in Lake view site, than Eastown site which is due to the use of screen and media filters in Lake view site, and screen filters only in Eastown site.

6- The turf quality index (color, density, ground cover) give high degree when using treated wastewater compare with domestic water, this is due to the nutrients in wastewater.

\section{REFERENCES}

AL-Amoud A.I. (1997). Trickle irrigation system, King Sand University, pp. 137-143.

Awady M.N., Vis E.G., Kumar R. and Mitra S. (2003). Distribution uniformity from pop-up sprinklers and landscape water-saving. Misr J. Ag. Eng. 20, 181-194.

Costello L.R., Matheny N.P. and Clark J.R. (1993). Estimating water requirements of landscape plantings, the landscape coefficient method, Crop. Ext., U.C. Division of Agriculture and Natural Resources, Leaflet 21493.

Carr G., Potter R.B. and Nortcliff S. (2011). Water reuse for irrigation in Jordan: perceptions of water quality among farmers. Agric. Wat. Manage. 98, 847-854.

El-Tantawy M.T. (2006). Evaluation of locally manufactured cylindrical screen filters. Fourth International Water Technology Conference, IWTC 99, Alexandria, Egypt, pp. 241-253.
Hamoda M.F. (2004). Water strategies and potential of water reuse in the south. Mediterranean countries. Desalination. 165, 31-41.

Hochstrat R., Wintgens T. and Melin T. (2008). Development of integrated water reuse strategies. Desalination. 218, 208-217.

IA. (2005). Landscape irrigation scheduling and water management, $22 \mathbf{p}$.

IA. (2009). WaterSense Commercial and Institutional Sector Comments, 2 p.

Irrigation Association (2001). Predicting and estimating landscape water use. Cited from ElZakaziky, M.M.O. (2012), Modeling of integrated water management for landscape irrigation, Ph.D. Thesis, Fac. of Agric., Ain Shams Univ., Cairo, Egypt.

Juan G. (2014). Water quality and water-use efficiency in landscapes, a training maual developed for landscape maintenance, personnel, Water Wise Consulting, Inc. 300 S. Raymond Ave., Suite 20 Pasadena, CA 91105, 626-7934200.

Keller J. and Karmeli D. (1974). Trickle irrigation design parameters, transactions of the ASAE, 1974.

Khaseeva K.A. (2013). Evaluation of turf quality for cool season species and cultivars, Russian St. Ag. U., Moscow, Russia, 92, 115-129.

Kumar J., Yadav M. and Srivastava S. (2017). Performance and Backwashing Efficiency of Screen, Disc and Sand Filters in Micro-Irrigation Systems. Trends in Biosciences 10, 21272178.

Mizyed N.R. (2013). Challenges to treated wastewater reuse in arid and semi-arid areas. Environmental Science \& Policy. 25, 186-195.

Nakayama F.S., Boman B.J. and Pitts D.J. (2007). Maintenance. In: Lamm, F.R., Ayars, J.E., Nakayama, F.S. (Eds.), Microirrigation for Crop Production. Design, Operation, and Management. Elsevier, Amsterdam, pp. 389-430.

Pescod M.B. (1992). Wastewater treatment and use in agriculture. FAO, Rome: 125 p.

WHO, World Health Organization (2006). Guidelines for the safe use of wastewater, excreta and greywater. Volume 2: Wastewater use in agriculture, Geneva. Switzerland. pp. 1-196. 


$$
\text { قسم الهنسة الزراعية - كلية الزراعة - جامعة عين شمس ابراء الايب" - محمود محمد حجازى - أسامة محمد أحمد بدير } 68 \text { - حدائق شبرا } 11241 \text { - القاهرة - مصر }
$$

*Corresponding author: Elshymaa Hamed@agr.asu.edu.eg

Received 21 July, 2020

Accepted 17 September, 2020

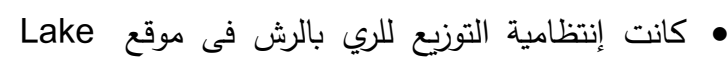

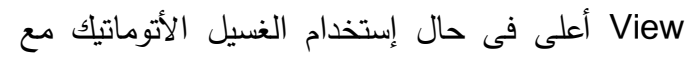

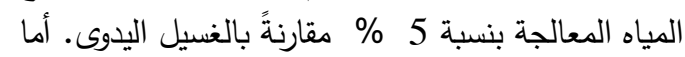
فى موقع Eastown كانت إنتظامية التوزيع أعلى في مانى

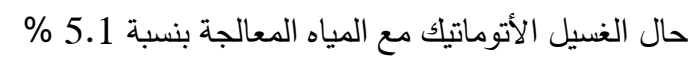

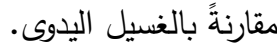

• كانت نسبة الإنسداد فى موقع Lake View في حال الئرئ

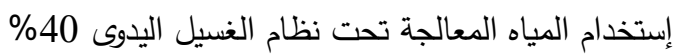
للمنقطات on-line و 48\% للمنقطات built-in وفى الئن

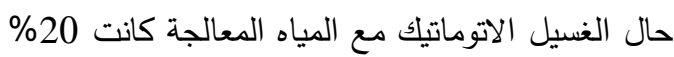

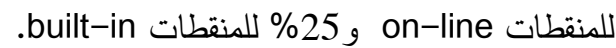
• كانت نسبة الإنسداد لموقع Eastown في حال استخدام المياه المعالجة تحت نظام الغسيل اليدوى 34.5\% للمنقطات on-line و 44.7 \% للمنقطات built-in وفى حال الغسيل الاتوماتيك مع المياه الدعالجة كانت

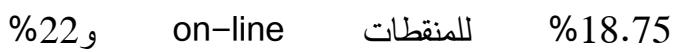
للمنقطات built-in • يضضل إستخدام المرشحات الرملية قبل المرشحات الشبكية

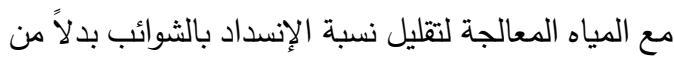
استخدام المرشحات الشبكية فقط. • لوحظ تأثر النبات المنزرع من خلات النيكة مشاهدة (اللون كثافة النبات - نسبة تغطية للمسطح) حيث كان أفضل فى حال استخدام المياه المعالجة عن المياه العادية.

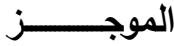


الصحي على أداء مكونات شبكات الري الضي الضغطي الضياه ومقارنتها بالمياه العادية.

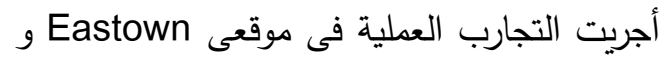
Lake view



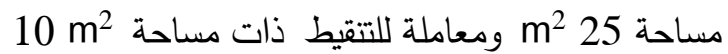

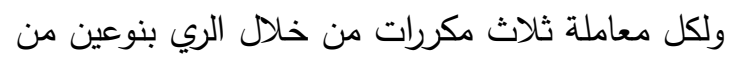

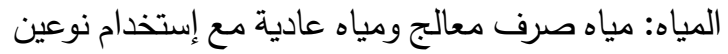
من المرشحات فى موقع Lake view (مرشح شبكى إنى ومرشح رملى) واستخدام نوع واحد من المرشحات فى في لمات

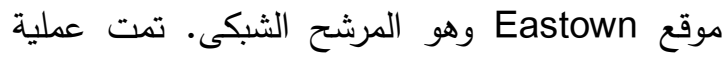
الغسيل يدوياً وأتوماتيكياً... وأظهرت النعات النتائج تاثيرات معنوية على مكونات الشبكة وعلى المظهر العام لحيوية وشكل المسطحات المنزرعة. وكانت أهم النيكة النتائج المتحصل عليها:

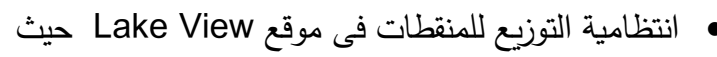
كانت أعلى فى حال إستخدام الغسيل الأتوماتيك مع المئل

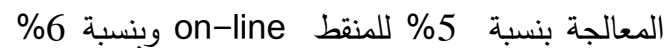

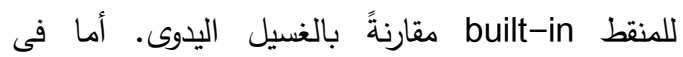
موقع Eastown كانت إنتظامية التوزيع أعلى في حال

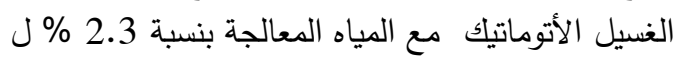

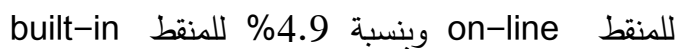

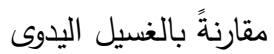

